\title{
Nutrient Leaching Loss of Pre-Treated Struvite and Its Application in Sudan Grass Cultivation as an Eco-Friendly and Sustainable Fertilizer Source
}

\author{
Arif Reza ${ }^{1,2,+}{ }^{\oplus}$, Soomin Shim ${ }^{1,+}$, Seungsoo Kim ${ }^{1}$, Naveed Ahmed ${ }^{1,3}{ }^{\mathbb{D}}$, Seunggun Won ${ }^{4}$ and \\ Changsix $\operatorname{Ra}^{1, *(\mathbb{D})}$ \\ 1 Department of Animal Industry Convergence, College of Animal Life Sciences, Kangwon National \\ University, Chuncheon 24341, Korea \\ 2 Department of Environmental Science, College of Agricultural Sciences, IUBAT-International University of \\ Business Agriculture and Technology, Dhaka 1230, Bangladesh \\ 3 U.S. Pakistan Center for Advanced Studies in Water, Mehran University of Engineering and Technology, \\ Jamshoro 76062, Pakistan \\ 4 Department of Animal Resources, College of Life and Environmental Science, Daegu University, \\ Gyeongsan 38453, Korea \\ * Correspondence: changsix@kangwon.ac.kr; Tel.: +82-33-250-8618 \\ + These authors contributed equally to this work.
}

Received: 1 July 2019; Accepted: 2 August 2019; Published: 3 August 2019

\begin{abstract}
Struvite recovered from waste streams is considered as a sustainable alternative to commercial phosphate $(\mathrm{P})$ fertilizers manufactured from P rock. In this study, struvite was recovered from swine wastewater and pre-treated as air-dried material (AM), microwave irradiated material $(\mathrm{MM})$, oven-dried material (OM), and incinerated material (IM) to reduce the moisture content. Based on their solubility and crystalline nature, AM and IM were selected for further experiments. The nutrient leaching loss and fertilizing value of AM and IM were evaluated in comparison to commercial fused superphosphate (FSP) fertilizer. Soil columns were used to quantify ortho-phosphate (O-P) and ammonium nitrogen $\left(\mathrm{NH}_{4}-\mathrm{N}\right)$ leaching in soil from the test materials. Among the test materials, the average leaching rate of O-P for FSP and AM was significantly different from the control and IM $(p<0.05)$. The average leaching rate of $\mathrm{NH}_{4}-\mathrm{N}$ among the test materials did not show any significant difference $(p>0.05)$. Sudan grass growth was examined with standard (urea supplemented) and high (20x, without urea) application of test materials in pot and soil box trials, respectively, to study the fertilizing value AM and IM. There were no significant differences among the test materials, except for the control, in terms of growth rate and fresh and dry matter yield in the pot trials $(p>0.05)$. When AM, IM, and FSP were applied in increasing amounts (20x) without urea supplement, Sudan grass growth was 50\% lower in IM and was found to be significantly different from AM and FSP $(p<0.05)$. The results suggest that struvite pre-treated as AM could be an effective sustainable and eco-friendly alternative to commercial $\mathrm{P}$ fertilizers and thus helps to ensure agricultural sustainability.
\end{abstract}

Keywords: Struvite; swine wastewater; pre-treatment; leaching; Sudan grass

\section{Introduction}

Phosphorus $(\mathrm{P})$ is one of the essential elements required for growth and cellular function of all life forms and is obtained primarily from rock phosphate. The phosphate rock reserves are nonrenewable and estimated to be 70,000 million tons as $\mathrm{P}_{2} \mathrm{O}_{5}$ [1]. Every year, 40 million tons of phosphate rock has been used for fertilizer, feed additive, and detergent production [2]. Moreover, the consumption of $\mathrm{P}$ is increasing by $1.5 \%$ per year and with the present consumption rate, the P reserves are expected to 
diminish within the next 90-300 years [2-4]. Due to non-substitutability and high economic importance, the European Commission (EC) has included phosphate rock to the list of 20 critical raw materials $[5,6]$. Therefore, an alternative, sustainable, and renewable source of $\mathrm{P}$ is needed to meet the demands of agriculture and livestock.

Fertilizers are added to the soil to stimulate crop growth and development. Owing to morphological characteristics, livestock manure and compost generated from the recycling of resources are generally applied to the soil as a basal dressing to improve the soil properties and support crop growth [7]. However, soil application of livestock manure and compost is not sufficient in terms of complete resource circulation and sustainable retention of nutrients. As a soil amendment, biochar is more advantageous than livestock manure and compost in terms of supplying nutrients [8]. Moreover, livestock manure and compost are difficult to use as additional fertilizer when the crop is actively growing and after the rainy season, therefore farmers are relying heavily on chemical fertilizers to replenish soil fertility. However, chemical fertilizers release nutrients quickly that are either lost in surface runoff and leaching or adsorbed on the soil particles and become unavailable for the plants at later growth stages [9]. Moreover, excessive nutrient inputs above crop requirement and low nutrient use efficiency of the crops may lead to exceeding the circulation capacity of the soil system, resulting in soil nutrient accumulation. The soil nutrient accumulation by excess application of chemical fertilizers, livestock manure, and compost is considered a serious concern worldwide. To ensure sustainable and complete circulation of resources in an agro-ecosystem, a balance between the direct application of livestock manure/compost and replacement of the use of chemical fertilizer with nutrients recovered from different waste sources is required.

For the past two decades, P refinery technologies to recover and recycle P from waste streams have been gaining more attention for agricultural as well as industrial purposes. Several studies have been focused on recovering P from different alternative waste sources including human and livestock wastewater and other bioresources (e.g., struvite) [3]. P recovered as struvite from highly polluted swine wastewater can be a sustainable alternative for chemical fertilizers as $\mathrm{N}$ and $\mathrm{P}$ concentration in swine wastewater is very high $[10,11]$. Usually, an addition of $\mathrm{Mg}$ source is required for struvite precipitation as swine wastewater contains a small amount of $\mathrm{Mg}$. Compared to chemical fertilizers, the struvite releases nutrients very slowly for a long time, which makes it quite useful in reducing $\mathrm{N}$ and $\mathrm{P}$ losses in soil, cost-effective, eco-friendly, and helps to ensure agricultural sustainability [12]. Apart from reducing nutrient loading to the soil from livestock manure and compost, minimizing the chemical fertilizer uses, and maintaining the soil nutrient balance, through the struvite recovery process, the depletion of $P$ rock reserves can be delayed.

Due to the increasing demand for meat and dairy products, livestock farms are becoming industrialized and depend heavily on nutritional fodder crops. Sudan grass (Sorghum sudanense) is one of the highly nutritive fodder crops that requires less input. The carrying capacity of Sudan grass is comparatively higher than other annual grasses and legumes and can be grown as an emergency crop in adverse conditions [13]. It is drought-resistant, requires less water to grow, and can recover faster than maize after drought [14-16]. Hence, its cultivation is gaining more popularity in countries with hot and dry summers [13]. Although the application of struvite as a fertilizer has been studied on different plants [17-21], none of the studies have focused on Sudan grass production.

After recovery, struvite precipitates generally have high moisture content. The drying of recovered struvite is therefore needed for its further use as a sustainable and eco-friendly fertilizer source. Among the different drying pre-treatments, air-drying, microwave irradiation, oven drying, and incineration have been widely used. In this study, the effects of different drying pretreatment techniques on reducing the moisture content of recovered struvite precipitates was investigated. Our hypothesis was that struvite pre-treated as air-dried material (AM), microwave irradiated material (MM), oven-dried material (OM), and incinerated material (IM) may be soluble and efficient in supplying $P$ to the crops as a sustainable alternative to the chemical fertilizers, thereby protecting the environment and ensuring agricultural sustainability. Therefore, the specific aims of this study were to evaluate the nutrient 
leaching loss of pre-treated struvite recovered from swine wastewater and agronomic performance as a sustainable and eco-friendly fertilizer source in Sudan grass growth trials.

\section{Materials and Methods}

\subsection{Struvite Recovery Process and Pre-Treatment}

The struvite recovery process used in this study was described in detail in our earlier study [22]. The swine wastewater was collected from a storage tank of a piggery located in Chuncheon, South Korea and stored in a $25 \mathrm{~L}$ jar at $4{ }^{\circ} \mathrm{C}$. To facilitate struvite formation, $\mathrm{MgCl}_{2}$ with respect to ortho-phosphate (O-P) was added to the process together with the influent. The recovered struvite was then pre-treated as air-dried material (AM), microwave irradiated material (MM), oven-dried material (OM), and incinerated material (IM) to reduce the moisture content for using afterwards (Table 1).

Table 1. Summary of the Pre-treated methods used in this study.

\begin{tabular}{ccc}
\hline Parameters & Pre-Treatment Method & References \\
\hline $\mathrm{AM}^{1}$ & Dried at $20^{\circ} \mathrm{C}$ for 14 days & This study \\
$\mathrm{MM}^{2}$ & $80 \mathrm{~Hz} \mathrm{~g}^{-1}$ for $5 \mathrm{~min}$ & This study \\
$\mathrm{OM}^{3}$ & Dried at $105^{\circ} \mathrm{C}$ for $24 \mathrm{~h}$ & {$[23]$} \\
$\mathrm{IM}^{4}$ & Incinerated at $550{ }^{\circ} \mathrm{C}$ for $30 \mathrm{~min}$ & {$[24]$} \\
\hline dried material; ${ }^{2} \mathrm{MM}=$ microwave irradiated material; ${ }^{3} \mathrm{OM}=$ oven-dried material; ${ }^{4} \mathrm{IM}=$ incinerated
\end{tabular}

\subsection{Solubility of the Pre-Treated Struvites}

The solubility of pre-treated struvites (AM, MM, OM, and IM) was investigated at different $\mathrm{pH}$ levels $(5.9,7$, and 8$)$. The $\mathrm{pH}$ of the solubility test was selected based on relevancy to the soil environment [20]. Solubility experiments were performed by mixing $2 \mathrm{~g}$ of samples in $100 \mathrm{~mL}$ of distilled water and the mixtures were placed on a rotary shaker for $30 \mathrm{~min}$ at $120 \mathrm{rpm}[20,25]$. The samples were then filtered using Whatman filter paper no. 2 (pore size $8 \mu \mathrm{m}$ ) and O-P was measured.

\subsection{Selection of Test Materials}

Among the pre-treated test materials, AM and IM were evaluated in nutrient leaching loss and Sudan grass growth tests. The materials were selected based on their crystalline nature and solubility in the soil environment.

\subsection{Soil Column Leaching Test}

The leaching loss of AM and IM was investigated from April to August of 2013 using soil columns and was compared with commercial fused superphosphate (FSP) fertilizer. First, 12 columns were prepared for the experiment with three replicates of four treatments including the control. Plexiglas tubes $55 \mathrm{~cm}$ long with an inside diameter of $8 \mathrm{~cm}$ and cross-sectional area of $0.005 \mathrm{~m}^{2}$ were used as soil columns. A stop valve was installed at the bottom of the column for leachate collection. The bottom $5 \mathrm{~cm}$ of the soil columns were packed with coarse sand, then $25 \mathrm{~cm}$ with sandy soil, and the top $5 \mathrm{~cm}$ with sandy soil + test materials. Detailed physico-chemical properties of the experimental soil are presented in Table 2. The soil columns were saturated with water prior to starting the experiment. Solids precipitated with struvite resulted in low $\mathrm{P}$ content in the AM. The FSP $\left(\mathrm{P}=92.8 \mathrm{~g} \mathrm{~kg}^{-1} ; \mathrm{N}=\right.$ $56.3 \mathrm{~g} \mathrm{~kg}^{-1}$ and $\left.\mathrm{Mg}=27.2 \mathrm{~g} \mathrm{~kg}^{-1}\right), \mathrm{AM}\left(\mathrm{P}=119.4 \mathrm{~g} \mathrm{~kg}^{-1} ; \mathrm{N}=55.3 \mathrm{~g} \mathrm{~kg}^{-1}\right.$ and $\left.\mathrm{Mg}=100.0 \mathrm{~g} \mathrm{~kg}^{-1}\right)$, and $\mathrm{IM}\left(\mathrm{P}=179.5 \mathrm{~g} \mathrm{~kg}^{-1} ; \mathrm{N}=0.03 \mathrm{~g} \mathrm{~kg}^{-1}\right.$ and $\left.\mathrm{Mg}=115.4 \mathrm{~g} \mathrm{~kg}^{-1}\right)$ were applied according to the Sudan grass $\mathrm{P}$ requirement (Table 3 ). The deficit in $\mathrm{N}$ was therefore adjusted by adding urea (Table 3$)$. The test materials were placed about $2-3 \mathrm{~cm}$ below the surface layer. Distilled water was added to a level of $5 \mathrm{~cm}$ from the surface layer. Sampling was done weekly by opening the stop valve and the water in the columns was adjusted. 
Table 2. Physico-chemical properties of the experimental soil.

\begin{tabular}{|c|c|c|}
\hline Parameter & Mean & Std. dev. \\
\hline $\mathrm{pH}$ & 6.56 & 0.11 \\
\hline $\mathrm{EC}^{1}\left(\mathrm{dS} \mathrm{m}^{-1}\right)$ & 0.53 & 0.02 \\
\hline $\mathrm{OM}^{2}\left(\mathrm{~g} \mathrm{~kg}^{-1}\right)$ & 11.12 & 0.16 \\
\hline $\mathrm{TN}^{3}\left(\mathrm{~g} \mathrm{~kg}^{-1}\right)$ & 0.30 & 0.03 \\
\hline $\mathrm{TP}^{4}\left(\mathrm{mg} \mathrm{kg}^{-1}\right)$ & 197.47 & 26.22 \\
\hline Total $\mathrm{K}^{5}\left(\mathrm{~mol} \mathrm{~kg}^{-1}\right)$ & 0.72 & 0.11 \\
\hline Total $\mathrm{Mg}^{6}\left(\mathrm{~mol} \mathrm{~kg}^{-1}\right)$ & 1.58 & 0.17 \\
\hline Total $\mathrm{Ca}^{7}\left(\mathrm{~mol} \mathrm{~kg}^{-1}\right)$ & 3.21 & 0.09 \\
\hline
\end{tabular}

${ }^{1} \mathrm{EC}=$ Electrical conductivity; ${ }^{2} \mathrm{OM}=$ Organic matter; ${ }^{3} \mathrm{TN}=$ Total nitrogen; ${ }^{4} \mathrm{TP}=$
Potassiun; ${ }^{6} \mathrm{Mg}=$ Magnesium $;{ }^{7} \mathrm{Ca}=$ Calcium.

Table 3. Formulations of test materials used in the column leaching test.

\begin{tabular}{ccc}
\hline Test materials & Amount $(g)^{2, *}$ & ${\text { Urea }(g)^{3, *}}^{3}$ \\
\hline Control & 0 & 0 \\
FSP ${ }^{1}$ & 3.28 & 0.44 \\
AM & 3.39 & 0.51 \\
IM & 1.56 & 0.75 \\
\hline
\end{tabular}

${ }^{1} \mathrm{FSP}=$ Fused superphosphate; ${ }^{2}$ The amount of testing materials added into each column; ${ }^{3}$ The deficient $\mathrm{N}$ amount in each testing material was supplemented by urea; ${ }^{*}$ The numbers were calculated based on wet basis.

\subsection{Sudan Grass Cultivation}

\subsubsection{Pot Trial}

Pot trials of Sudan grass were conducted in a trial site at Kangwon National University, Chuncheon, South Korea from May to September of 2013. The effect of AM and IM on the growth and fresh and dry matter yield of Sudan grass was evaluated and compared with FSP. Based on the recommended application rate of $\mathrm{P}\left(56 \mathrm{~kg} \mathrm{ha}^{-1}\right)$ and $\mathrm{N}\left(150 \mathrm{~kg} \mathrm{ha}^{-1}\right)$ for Sudan grass, the $\mathrm{P}$ and $\mathrm{N}$ were added into the pots (Table 4) [26]. Urea $(46 \% \mathrm{~N})$ was used to fulfill the $\mathrm{N}$ requirement as struvite contains only $6 \% \mathrm{~N}$. The FSP or AM or IM was mixed with the top $5 \mathrm{~cm}$ of the base soil (sandy soil). Twelve pots were prepared for the experiment with three replicates of four treatments including the control. The pots that were used for the experiments were $47 \mathrm{~cm}$ in height with an inside top and bottom diameter of $40 \mathrm{~cm}$ and $25 \mathrm{~cm}$, respectively. The pot to pot distance was $30 \mathrm{~cm}$ and seeds were sown at $3 \mathrm{~cm}$ depth with a seeding rate of 20 seeds pot $^{-1}$. The pots were watered three times a week and watering was maintained according to the amount of precipitation. The daily average temperature was $22.8^{\circ} \mathrm{C}$ (range, $6.1^{\circ} \mathrm{C}$ to $33.6^{\circ} \mathrm{C}$ ). During the experiment, no pesticide was used and intercultural operations were performed periodically. Crop lengths were measured weekly; fresh and dry matter yield were estimated after the primary and secondary harvest at 66 and 124 days, respectively, and summed to obtain the total yield.

Table 4. Amount of test materials and urea applied as fertilizer for Sudan grass production in pots and soil box trials.

\begin{tabular}{|c|c|c|c|c|}
\hline \multirow{2}{*}{ Contents } & \multicolumn{2}{|c|}{ Pot Trials $\left(P=56 \mathrm{~kg} \mathrm{ha}^{-1} ; \mathrm{N}=150 \mathrm{~kg} \mathrm{ha}^{-1}\right)$ * } & \multicolumn{2}{|c|}{ Soil Box Trials $(P=20 x ; N=0)$} \\
\hline & Amount $^{1}(g)$ & Urea $^{2}(g)$ & Amount $^{3}$ (g) & Urea (g) \\
\hline Control & 0 & 0 & 0 & 0 \\
\hline FSP & 8.221 & 1.096 & 164.4 & 0 \\
\hline $\mathrm{AM}$ & 8.509 & 1.278 & 170.2 & 0 \\
\hline $\mathrm{IM}$ & 3.916 & 1.884 & 78.3 & 0 \\
\hline
\end{tabular}

${ }^{*}$ Recommended $\mathrm{N}$ and $\mathrm{P}$ rates for the cultivation of Sudan grass; ${ }^{1}$ The amount of test materials added into each pot; ${ }^{2}$ Urea was added as a source $N{ }^{3}$ The amount of test materials added into each soil box. 


\subsubsection{Soil Box Trial}

To evaluate the efficacy of recovered struvite as a sustainable fertilizer source, another small trial was conducted in soil boxes without urea supplementation from June to September of 2013 using high doses (20x) of AM and IM along with FSP (Table 4). Soil boxes $(66 \mathrm{~cm} \times 40 \mathrm{~cm} \times 50 \mathrm{~cm}$ ) were prepared by adding $5 \mathrm{~cm}$ of coarse sand at the bottom and $35 \mathrm{~cm}$ sandy soil over it. The FSP or AM or IM was mixed thoroughly with the top $5 \mathrm{~cm}$ of sandy soil. Twelve soil boxes were prepared for the experiment with three replicates of four treatments including the control. The row to row and plant to plant distance were both kept at $5 \mathrm{~cm}$ with a seeding rate of 50 seeds box ${ }^{-1}$. During the experiment, the daily average temperature was $24.0^{\circ} \mathrm{C}$ (range, $10^{\circ} \mathrm{C}$ to $33.6^{\circ} \mathrm{C}$ ). Watering and other intercultural operations were the same as described earlier. The crop lengths were measured weekly; fresh yield and dry matter yield were estimated after the primary and secondary harvest at 49 and 83 days, respectively, and summed to obtain the total yield.

\subsection{Analytical Methods}

The concentrations of total solids (TS), suspended solids (SS), O-P, ammonium nitrogen $\left(\mathrm{NH}_{4}-\mathrm{N}\right)$, total phosphorus (TP), and total nitrogen (TN) in influents and effluents were measured according to the standard methods [27]. Solids were separated from the sample through centrifugation and the supernatant was used for further chemical analysis. O-P, $\mathrm{NH}_{4}-\mathrm{N}, \mathrm{TP}$, and $\mathrm{TN}$ were analyzed using auto-analyzer (Quik Chem 8500, Lachat, Milwaukee, WI, USA). TP and TN were analyzed after digesting in a block digester with $5 \mathrm{~N} \mathrm{H}_{2} \mathrm{SO}_{4}$ for $4 \mathrm{~h}$ at $380^{\circ} \mathrm{C}$. The selected heavy metal contents (based on the Korean standard and fertilizer guidelines suggested by the Rural Development Administration of Korea) in the recovered struvite were determined using Inductively Coupled Plasma Atomic Emission Spectroscopy (ICP-AES) (Optima 7300 DV, PerkinElmer, Waltham, MA, USA). The properties of the pre-treated struvites were identified using the X-ray diffraction (XRD) (PANalytical X'Pert-PRO MPD, Malvern Panalytical BV, Almelo, The Netherlands). The fresh samples were dried at $105^{\circ} \mathrm{C}$ for $24 \mathrm{~h}$ for the dry matter yield determination. Crop length and fresh and dry matter yield were estimated using the official methods of analysis [23].

\subsection{Statistical Analysis}

Statistical analysis was performed using the GraphPad Prism (version 5.03, 2009). Differences in means among the treatments were analyzed with one-way ANOVA and the significant differences among the treatments were compared using Tukey's HSD post-hoc test.

\section{Results and Discussion}

\subsection{Struvite Recovery from Swine Wastewater}

Table 5 shows the performance of the struvite recovery process. The mean removal efficiencies of O-P and $\mathrm{NH}_{4}-\mathrm{N}$ were approximately $73.96 \%$ and $21.97 \%$, respectively. The removal efficiency of O-P is associated with struvite recovery [22]. Due to struvite crystallization and air stripping, $\mathrm{NH}_{4}-\mathrm{N}$ removal efficiency is higher than the theoretical value of $7 \%$. The struvite recovery efficiency is highly dependent on the waste source type and experimental conditions such as $\mathrm{pH}$ and ionic molar ratios $[28,29]$. Previous studies reported that very pure forms of struvite can be recovered from swine wastewater at $\mathrm{pH} 8.0$ to 9.0 and an Mg:P molar ratio of 0.8:1 to 1.2:1 [22,30,31]. The $\mathrm{pH}$ of the influent used in this study was 8.69 and therefore no additional chemical was used to control the $\mathrm{pH}$ during the recovery process. In this study, the struvite was recovered at $\mathrm{pH} 8.52$ and an Mg:P molar ratio of 1.2:1. The mean removal efficiencies of TS and SS were $42.67 \%$ and $77.86 \%$, respectively. A small amount of heavy metals (very low compared to the Korean standard for fertilizer raw materials) was detected in the recovered struvite (Table 6). All the ingredients in the struvite recovered from animal wastewater originated from the animal feedstock containing low heavy metal and the recovered struvite therefore needs lesser efforts to purify for target use such as fertilizer and in chemical industries [21]. 
The swine wastewater management system in Korea is quite different compared to other countries. Due to rapid economic return, the swine farming system in Korea is becoming more intensive. Intensification in swine farms resulted in an increase of the swine population from around 3.6 million in 1983 to 11.3 million in 2018 as well as wastewater generation [32]. The Korean Government has therefore imposed some strict regulations including the prohibition of the direct use of swine wastewater in agricultural fields and stringent nutrient concentration limits for swine wastewater discharge to protect the environment. The government has also established more than 200 centralized swine wastewater treatment plants all over Korea with a treatment capacity of more than 7.3 million ton per year and the number is still increasing $[33,34]$. The mass production of struvite from the centralized wastewater treatment plants might therefore be economically viable, help maintaining social equity, and protect the environment, thus ensuring sustainability.

Table 5. Performance of the struvite recovery process.

\begin{tabular}{cccccc}
\hline \multirow{2}{*}{ Parameter } & \multicolumn{2}{c}{ Influent } & \multicolumn{2}{c}{ Effluent } & Removal Efficiency \\
\cline { 2 - 5 } & Mean & Std. dev. & Mean & Std. dev. & (\%) \\
\hline $\mathrm{TS}^{1}\left(\mathrm{~g} \mathrm{~L}^{-1}\right)$ & 45.89 & 10.51 & 26.31 & 2.52 & 42.67 \\
$\mathrm{SS}^{2}\left(\mathrm{~g} \mathrm{~L}^{-1}\right)$ & 40.24 & 24.42 & 8.91 & 3.74 & 77.86 \\
$\mathrm{NH}_{4}-\mathrm{N}^{3}\left(\mathrm{mg} \mathrm{L}^{-1}\right)$ & 2977.46 & 661.61 & 2323.40 & 589.56 & 21.97 \\
$\mathrm{O}^{4} \mathrm{P}^{4}\left(\mathrm{mg} \mathrm{L}^{-1}\right)$ & 53.11 & 9.62 & 13.83 & 12.75 & 73.96 \\
$\mathrm{TN}\left(\mathrm{mg} \mathrm{L}^{-1}\right)$ & 7656.7 & 971.5 & 6598.25 & 679.13 & 13.82 \\
$\mathrm{TP}\left(\mathrm{mg} \mathrm{L}^{-1}\right)$ & 174.5 & 25.42 & 55.69 & 56.55 & 68.09 \\
pH & & \multicolumn{2}{c}{8.52} & - \\
\hline
\end{tabular}

${ }^{1} \mathrm{TS}=$ Total solids $;{ }^{2} \mathrm{SS}=$ Suspended solids $;{ }^{3} \mathrm{NH}_{4}-\mathrm{N}=$ Ammonium nitrogen; ${ }^{4} \mathrm{O}-\mathrm{P}=$ Ortho-phosphate.

Table 6. Heavy metal concentrations in recovered struvite.

\begin{tabular}{|c|c|c|}
\hline Heavy Metal & Struvite $\left(\mathrm{mg} \mathrm{kg}^{-1}\right)$ & Korean Standard for Fertilizer Raw Materials (mg kg-1) \\
\hline Arsenic & 0.0 & 45 \\
\hline Cadmium & 0.0 & 5 \\
\hline Chromium & 0.0 & 200 \\
\hline Copper & 17.86 & 360 \\
\hline Lead & 0.0 & 130 \\
\hline Mercury & ND* & 2 \\
\hline Nickel & 0.0 & 45 \\
\hline Zinc & 95.54 & 900 \\
\hline
\end{tabular}

\subsection{Pre-Treatment of Recovered Struvite}

The recovered struvite from the swine wastewater was precipitated in the reactor as dense fine particles. Therefore, the settled struvite precipitates were dried to evaporate the moisture and obtain struvite in powder form for further use. Among the pre-treatment techniques, air dry is simple and economical, but time consuming [35]. Whereas, microwave irradiation is a dielectric heating process where electromagnetic waves are produced by a magnetic and an electric field component. As a drying pre-treatment, it requires less time and ensures uniform drying of the material [36]. On the other hand, incineration and over dry are the conventional drying methods using high temperature. To study the effect of drying pre-treatments on the chemical composition of the recovered struvites, XRD analysis was performed. The XRD pattern (position and peaks intensity) generated from the pre-treated materials were matched with the reference values. Among the pre-treated struvites, AM showed the characteristic struvite structuration (magnesium ammonium phosphate (MAP), $\mathrm{MgNH}_{4} \mathrm{PO}_{4} \cdot 6 \mathrm{H}_{2} \mathrm{O}$ ) (Figure 1a), while MM showed several peaks indicative of MAP (Figure 1b). OM produced a thermally more stable product dittmarite, $\mathrm{MgNH}_{4} \mathrm{PO}_{4} \cdot \mathrm{H}_{2} \mathrm{O}$ (Figure 1c). Whereas, IM denatured the struvite to magnesium pyrophosphate $\left(\mathrm{Mg}_{2} \mathrm{P}_{2} \mathrm{O}_{7}\right)$ (Figure 1d) with the removal of ammonium and hydrates. 

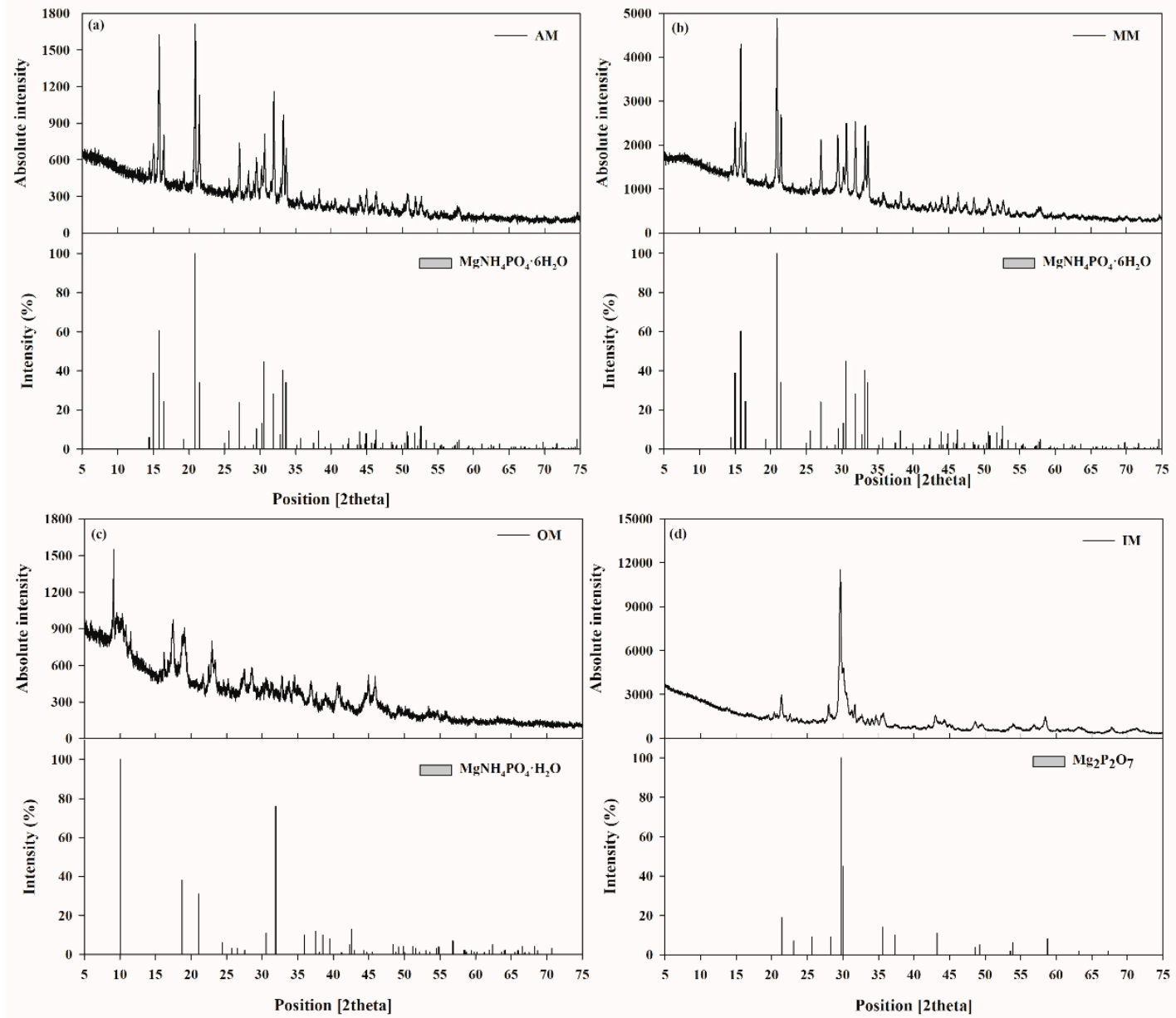

Figure 1. X-ray diffraction analysis of the (a) AM; (b) MM; (c) OM; (d) IM.

Nutrient contents of struvite vary significantly depending on the type of material used for struvite recovery. Struvite has $\mathrm{N}: \mathrm{P}_{2} \mathrm{O}_{5}: \mathrm{K}_{2} \mathrm{O}: \mathrm{Mg}$ content ratio of 5.7:29:0:16.4 [37]. $\mathrm{N}$ and P content in struvite usually ranges from $56-70 \mathrm{~g} \mathrm{~kg}^{-1}$ and $56-260 \mathrm{~g} \mathrm{~kg}^{-1}$, respectively [19-21]. The results of nutrient contents analysis reveal that drying pre-treatment can change the nutrient contents of struvite (Table 7). After pre-treatment, a decrease in $\mathrm{N}$ content of the pre-treated struvites was observed, whereas $\mathrm{P}$ content was well within range.

Table 7. Nutrient content and solubility of different pre-treated struvites.

\begin{tabular}{|c|c|c|c|c|c|c|c|}
\hline \multirow{3}{*}{ Parameter } & \multicolumn{3}{|c|}{ Nutrient Content $\left(\mathrm{g} \mathrm{kg}^{-1}\right)^{1}$} & \multicolumn{4}{|c|}{ Solubility (\%) } \\
\hline & \multirow{2}{*}{$\mathbf{N}$} & \multirow{2}{*}{$\mathbf{P}$} & \multirow{2}{*}{ Mg } & \multicolumn{3}{|c|}{$\mathrm{pH}$} & \multirow{2}{*}{ Range } \\
\hline & & & & 5.9 & 7.0 & 8.0 & \\
\hline AM & 55.3 & 119.4 & 100.0 & 9.64 & 2.28 & 7.38 & $7.0 \sim 9.9$ \\
\hline MM & 41.5 & 121.9 & 98.0 & 38.04 & 34.07 & 47.01 & $32.7 \sim 49.9$ \\
\hline $\mathrm{OM}$ & 19.6 & 121.4 & 100.3 & 74.28 & 46.59 & 53.41 & $45.7 \sim 75.8$ \\
\hline IM & 0.03 & 179.5 & 115.4 & 2.38 & 2.19 & 2.34 & $2.1 \sim 2.4$ \\
\hline
\end{tabular}

${ }^{1}$ All the figures are based on dry weight $\left(\mathrm{g} \mathrm{kg}^{-1}\right)$ basis.

To ascertain the fertilizer potential of the pre-treated stuvites, the solubility experiment was conducted. The solubility of struvites generally varies between $15-40 \%$ [20]. Table 7 shows the solubility of the pre-treated struvites at different $\mathrm{pH}$ levels. Among the pre-treated materials, AM and IM showed low solubility, while the solubility of MM and OM were similar to chemical fertilizer (60-95\% soluble) [20]. Based on solubility test results and crystalline nature, AM and IM were selected 
for further experiments. Although IM did not show the characteristic struvite structuration, due to low solubility, the nutrient leaching loss and agronomic performance of IM were investigated.

\subsection{Nutrient Leaching in Soil Column}

Nutrient leaching from control, FSP, AM, and IM in soil column is shown in Figure 2a. Nutrient

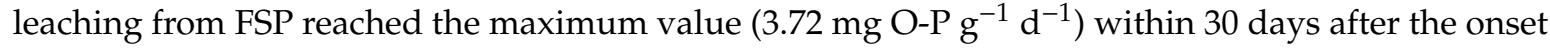
of the experiment and gradually decreased to $2 \mathrm{mg}^{\mathrm{O}}-\mathrm{P} \mathrm{g}^{-1} \mathrm{~d}^{-1}$ or less after 70 days. Whereas, AM

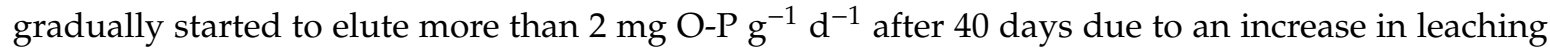
rate. After that, the leaching rate began to decrease and ranged between $1.85-2.56 \mathrm{mg} \mathrm{O}-\mathrm{P} \mathrm{g}^{-1} \mathrm{~d}^{-1}$ for about 2 months until the end of the experiment. In the case of IM, the average leaching rate was about 4.2 and 3.6 times lower than FSP and AM, respectively, and no decreasing pattern was observed during 18 weeks of the experiment. The average O-P leaching rate for control, FSP, AM, and IM was

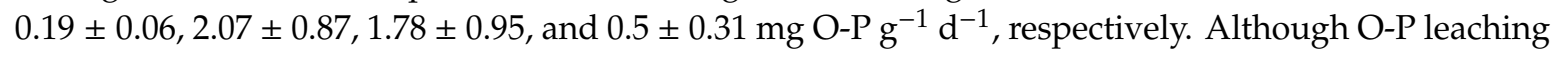
from FSP was faster than AM and IM (Figure 2a), the average leaching rate of O-P for FSP and AM was significantly different from the control and IM, while no significant difference was observed between FSP and AM $(p>0.05)$.

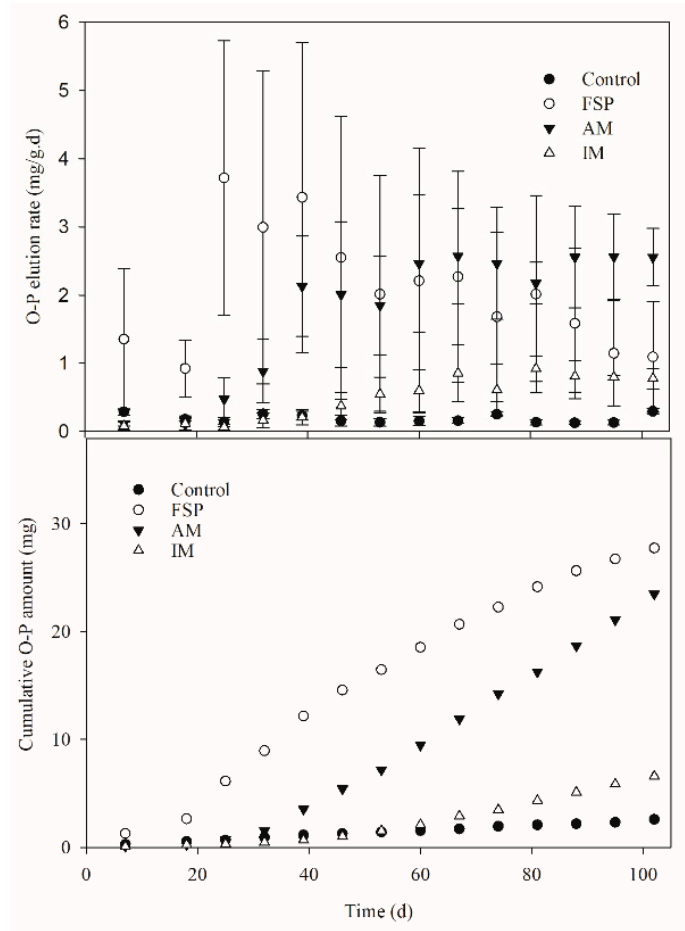

(a)

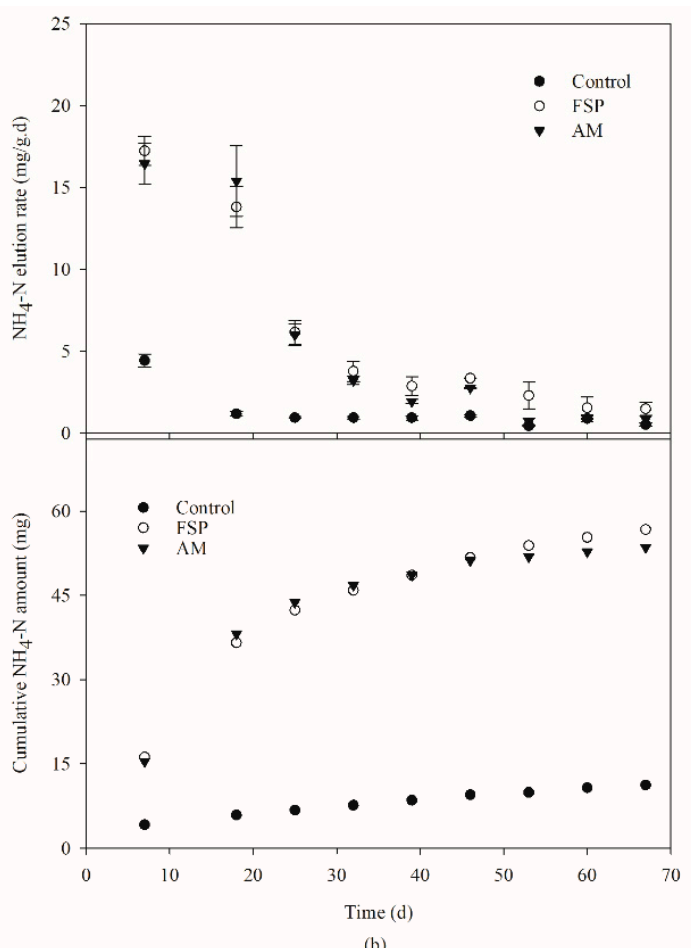

Figure 2. The average leaching rate and cumulative leaching amount of (a) O-P from control, FSP, AM, and IM (b) $\mathrm{NH}_{4}-\mathrm{N}$ from the control, FSP, and AM in the soil column experiment.

For the $\mathrm{NH}_{4}-\mathrm{N}$ leaching test, IM was not considered as it was incinerated at a high temperature $\left(550{ }^{\circ} \mathrm{C}\right)$ and most of the $\mathrm{N}$ was evaporated during incineration. However, a small fraction of $\mathrm{N}$ was present in the form of urea. Therefore, to determine the elution of $\mathrm{NH}_{4}-\mathrm{N}$ from FSP and AM, the concentration of ammonia $\mathrm{N}$ leached by urea was excluded. The average $\mathrm{NH}_{4}-\mathrm{N}$ leaching rate for the

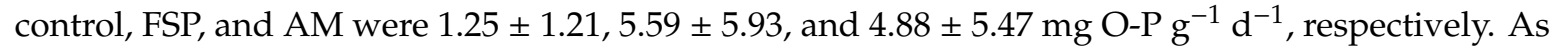
shown in Figure 2(b), the leaching profiles of $\mathrm{N}$ contained in commercial FSP did not differ significantly from that of $\mathrm{N}$ in $\mathrm{AM}(p>0.05)$.

The results of the soil column nutrient leaching experiments support earlier findings, which reported that nutrient leaching from struvite is lower than chemical fertilizers. Rahman et al. applied $30-40 \mathrm{~kg} \mathrm{ha}^{-1}$ struvite-Urea and FSP-Urea in a soil column and observed a P leaching of $0.03-0.37 \%$ 
and $0.23-0.25 \%$ for struvite and FSP, respectively [22]. Latifian et al. conducted a nutrient release experiment in a dialysis bag for 105 days and found that the commercial NPK fertilizer released $72 \%$ $\mathrm{O}-\mathrm{P}$ in just one day and reached a maximum release of $88 \%$ within 20 days, while struvite slowly released O-P and even after 105 days, the elution for struvite recovered from anaerobic digestion effluent was around $12 \%$ [38]. Sharma et al. applied di-ammonium phosphate (DAP) in a packed box experiment with sandy and loamy soils and reported a P leaching of 7-57\% in sandy soils and $27-67 \%$ of $P$ leaching in loamy soils. They found that over $90 \%$ of $P$ losses in sandy soils were via runoff and leaching in the form of dissolved unreactive $\mathrm{P}$ (DURP) and particulate $\mathrm{P}$ (PP), while dissolved reactive $\mathrm{P}(\mathrm{DRP})$ showed a minor contribution [39]. In sandy soils, $\mathrm{P}$ leached by vertical flow while leaching was governed by through flow in loamy soils. The relatively higher affinity of DRP with soil results in less mobility compared to other forms of $\mathrm{P}$ [39]. A critical limit of $0.1 \mathrm{mg}-\mathrm{P} \mathrm{L}^{-1}$ for leaching set by USEPA to control eutrophication can therefore be easily maintained using struvite due to its slow-releasing characteristics.

Ryu and Lee reported the slow-releasing character of struvite recovered from swine wastewater compared to complex fertilizer by applying $100 \mathrm{mg}-\mathrm{N} \mathrm{kg}^{-1}$ in a $40 \mathrm{~h}$ soil column experiment [40]. Maximum $\mathrm{NH}_{4}-\mathrm{N}$ leaching from complex fertilizer was reported within $2 \mathrm{~h}$ compared to struvite. In another $48 \mathrm{~h}$ column leaching experiment, Ryu et al. observed that within a short period of time $(<10 \mathrm{~h})$, complex fertilizer reached the steady-state, while struvite recovered from semiconductor wastewater required more than $40 \mathrm{~h}$ and the cumulative leached $\mathrm{N}$ mass from complex fertilizer and struvite was about $32.9 \%$ and $17.6 \%$ at the steady state, respectively [41]. Latifian et al. also observed a quick release of NPK fertilizer in the dialysis bag. They found that $57 \%$ of $\mathrm{NH}_{4}-\mathrm{N}$ was released within one day from commercial NPK fertilizer, whereas struvite released only $11 \% \mathrm{NH}_{4}-\mathrm{N}$ [38]. In another study, Rahman et al. observed a minute release of $\mathrm{NH}_{4}-\mathrm{N}$ from struvite (1.9-2.0\%) compared to commercial FSP fertilizer (7.8-6.4\%) when $30-40 \mathrm{~kg} \mathrm{ha}^{-1}$ fertilizer was applied in a soil column [22]. The results in this study are well in line with previous studies conducted using struvites and confirm that pre-treated struvite as a fertilizer source is more eco-friendly compared to chemical fertilizers by slowly releasing nutrients into soil.

\subsection{Effects of Test Materials on Sudan Grass Production}

The use of struvite as a fertilizer was first proposed by Sir James Murray in 1858 [19]. The struvite is generally applied as $\mathrm{P}$ fertilizer, therefore supplementation of $\mathrm{N}$ needs to be considered to fulfill the nutrient requirements of any specific crop [42]. In this study, urea was applied as a supplementary $\mathrm{N}$ source to meet $\mathrm{N}$ deficiency in pot trials of Sudan grass. No significant difference was observed in the germination rate (average 66.3\%) for all the test materials including the control $(p>0.05)$ (data not shown). The crop growth was visually compared during a 124 day experiment. Figure 3a shows that the effects of FSP, AM, and IM on Sudan grass growth was similar except for the control. The growth rate of Sudan grass using the control, FSP, AM, and IM treatments were calculated as $8.1 \pm 0.1$, $12.6 \pm 0.4,12.8 \pm 0.7$, and $12.6 \pm 0.5 \mathrm{~mm} \mathrm{~d}^{-1}$, respectively. The growth rates were not significantly different among test materials except for the control $(p>0.05)$ (Figure 3a). These results are highly consistent with previous studies. Li and Zhao observed no significant difference in the growth rate of the leaf or stalk length of cabbage, Chinese chard, water spinach, and water convolvulus when they were treated with struvite and chemical fertilizer [43]. However, Ryu et al. reported that the leaf length of struvite fertilized lettuce was almost double that of complex fertilizer [44]. In another study, Ryu et al. assessed the quality of semiconductor wastewater recovered struvite as a fertilizer and observed that leaf length and nutrient content in the tissues of struvite fertilized lettuce were higher than the complex fertilizer [41]. Liu et al. reported significantly higher leaf area with struvite treated maize compared to FSP [30].

Sudan grass is usually harvested after primary growth and is then allowed to regrow from the remaining portion. Figure 3a shows the secondary growth of the Sudan grass after its first harvesting. Initially, the growth was rapid for around two weeks and then it plateaued. The mean fresh yield 
for FSP, AM, and IM were $222.3 \pm 23.4,218.5 \pm 33.9$, and $242.3 \pm 5.8 \mathrm{~g} \mathrm{pot}^{-1}$, respectively; while the mean dry matter yield for FSP, AM, and IM were $53.1 \pm 5.8,52.6 \pm 7.9$, and $58.5 \pm 1.1 \mathrm{~g} \mathrm{pot}^{-1}$, respectively (Figure $3 \mathrm{~b}$ ). For fresh and dry matter yield, a significant difference between the control and test materials was observed, but no significant difference among treatments (FSP, AM, IM) was found $(p>0.05)$. Previous studies are in good agreement with this general finding. Johnston and Richards compared the effectiveness of several recovered struvite with commercial monocalcium phosphate for ryegrass growth and total dry matter yield and found no significant difference among the treatments [19]. Li and Zhao did not find any significant difference in fresh or dry yield for Chinese flowering cabbage, Chinese chard, water spinach, and water convolvulus with struvite and commercial fertilizer treatments [43]. Plaza et al. also reported no significant difference in the dry matter yield of ryegrass with 9-44 $\mathrm{mg}-\mathrm{P} \mathrm{kg}^{-1}$ struvite or superphosphate [45].
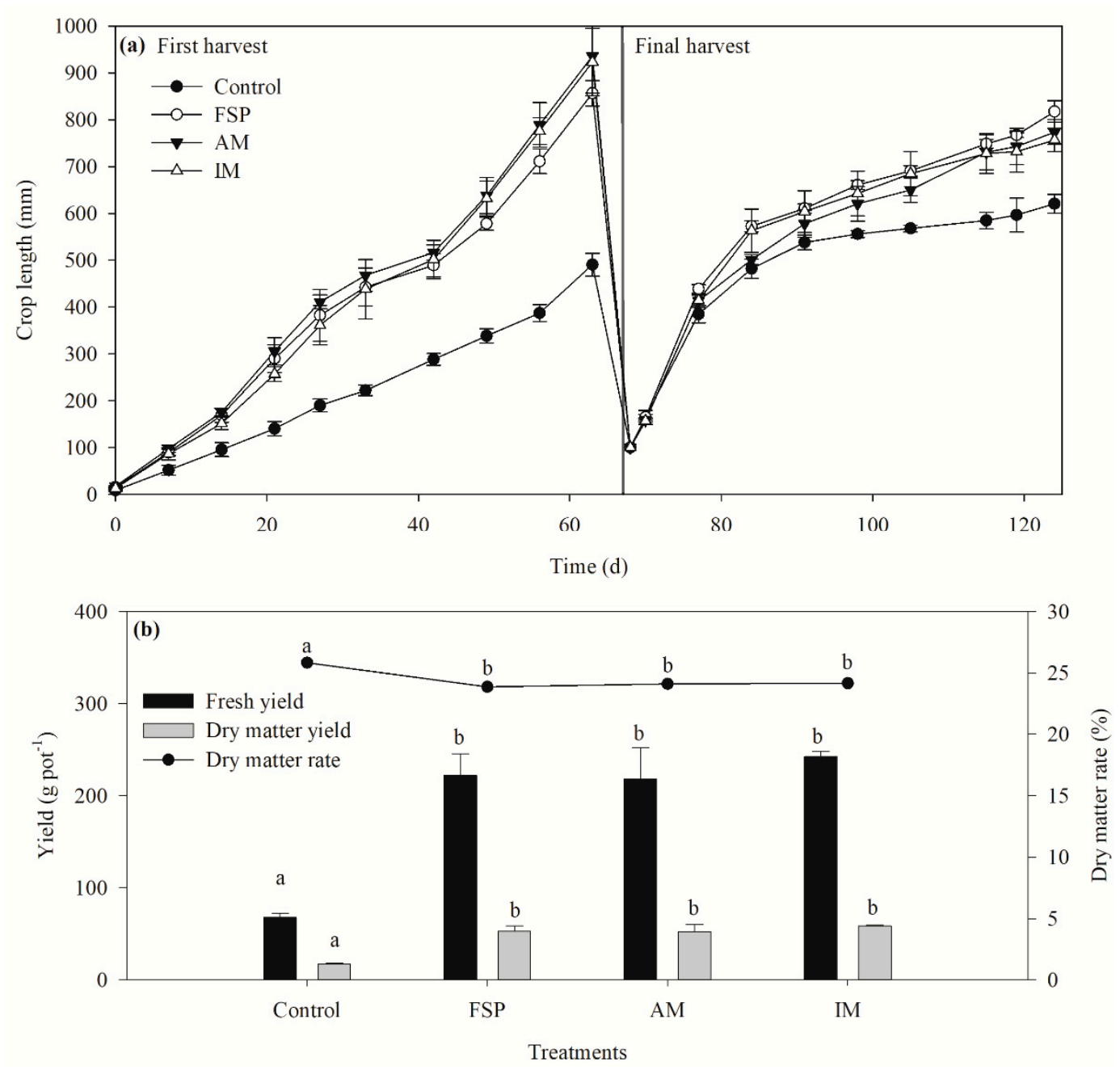

Figure 3. (a) Temporal variation of crop length and (b) total fresh yield, dry matter yield and dry matter rate as a function of the applied test materials in the pot trials. Treatment means with the same letter are not significantly different $(p>0.05)$.

In soil box trials, the FSP, AM, and IM were applied 20 times higher than the required amount for Sudan grass to check their suitability when supplementary $\mathrm{N}$ was not supplied (Table 4). No statistically significant difference was observed in the germination rate (average $70 \%$ ) among the test materials $(p>0.05)$ (data not shown). The growth rates were $28.4 \pm 1.4,27.1 \pm 0.8$, and $13.3 \pm 2.2 \mathrm{~mm} \mathrm{~d}^{-1}$ for FSP, AM, and IM treatments, respectively. As shown in Figure 4a, the growth rate obtained with the IM treatment was lower than that of the FSP and AM treatments. However, FSP and AM did not show 
any statistically significant difference $(p>0.05)$. The growth rate of Sudan grass using IM was less than $50 \%$ compared to FSP and AM treatments due to evaporation loss of $\mathrm{N}$ during incineration.
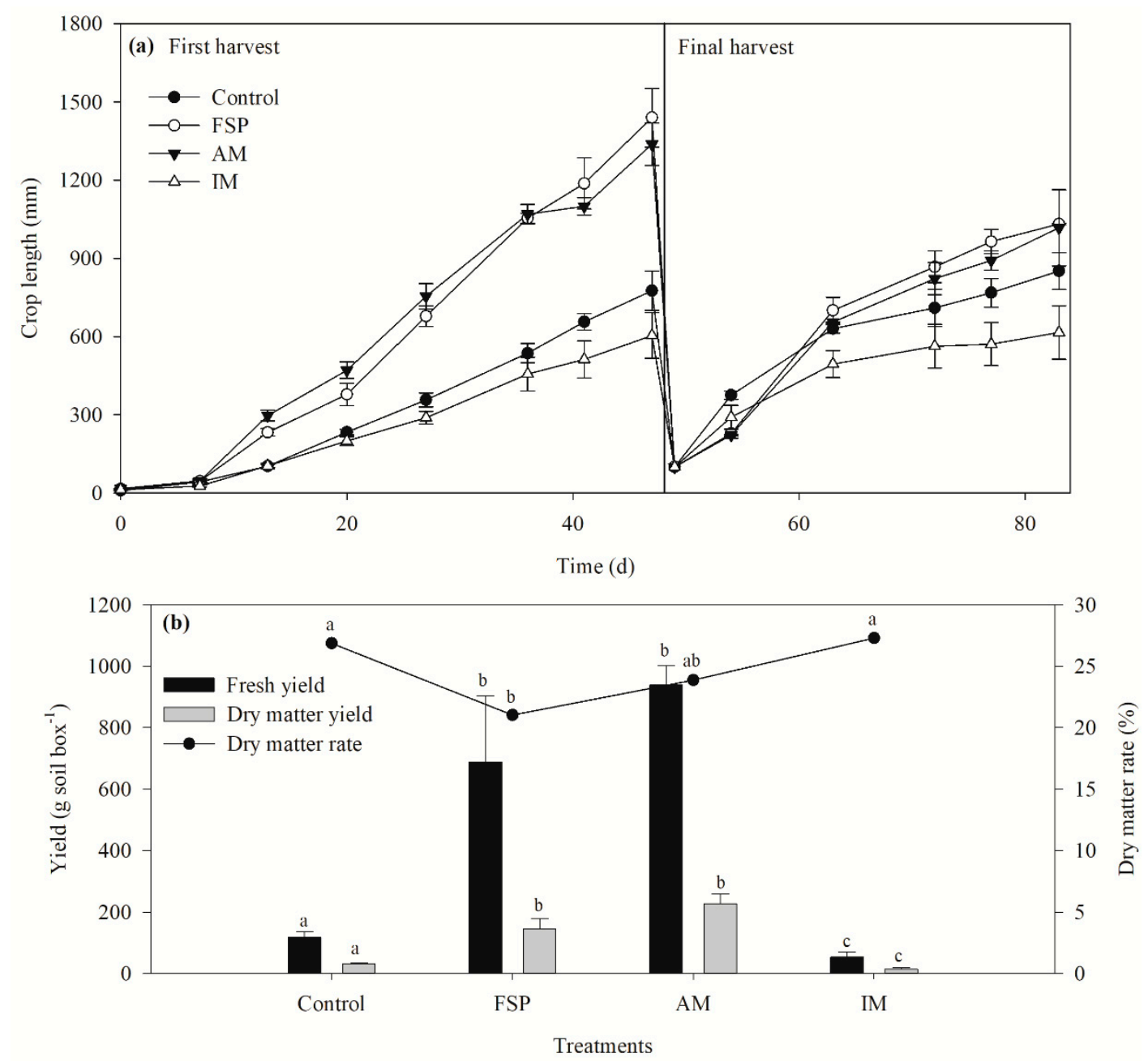

Figure 4. (a) Temporal variation of crop length and (b) total fresh yield, dry matter yield and dry matter rate as a function of the applied test materials in the soil box trials. Treatment means with the same letter are not significantly different $(p>0.05)$.

The fresh yield for FSP and AM were $688.9 \pm 214.6$ and $939.2 \pm 64.1 \mathrm{~g}^{2}$ soil box ${ }^{-1}$, respectively and were comparatively higher than IM treatment $\left(53.6 \pm 16.1 \mathrm{~g}\right.$ soil box $\left.^{-1}\right)$. No significant difference $(p>0.05)$ in fresh yield was found between FSP and AM treatments (Figure 4b). However, the dry matter percentage was significantly lower in the FSP treatment $(22.2 \%)(p<0.05)$. Our study revealed that increasing application of struvite as AM stimulates Sudan grass growth without any side effects. This finding is in line with other studies. Ryu et al. applied 0.1-0.6 and 0.3-1.3 g struvite $\mathrm{kg}^{-1}$ soil for lettuce growth and observed an increase in the leaf length, fresh yield, and dry yield with increasing application of struvite [44]. Li and Zhao applied 2-8 times higher doses of landfill leachate recovered struvite on water spinach and found no significant difference in the sprouts among the treatments without any burning effects [43]. Ackerman et al. applied 9.5-47.5 mgP pot ${ }^{-1}$ and observed that the biomass yield of canola increased from 5.4 to $9.6 \mathrm{~g} \mathrm{pot}^{-1}$ [46]. Uysal et al. increased struvite doses up to 4 times higher than the standard and found an increase in the growth and nutrient uptake of maize and tomato plants with the increasing amount of struvite [47]. Plaza et al. observed that increased struvite application in ryegrass did not affect $\mathrm{N}, \mathrm{K}$, and Ca uptake, while the P and $\mathrm{Mg}$ uptake increased significantly in both struvite and superphosphate [45]. Mg could be the reason for comparatively higher growth of plants with higher struvite applications as $\mathrm{Mg}$ complements $\mathrm{P}$ uptake [48]. The 
above-mentioned studies clarified that over-application of struvite as AM does not burn the roots as it is a slow-releasing fertilizer, but rather enhances the plant growth by higher $\mathrm{P}$ and $\mathrm{Mg}$ uptake.

\section{Conclusions}

Despite its low solubility and slow-releasing character, struvite is as effective as highly soluble fertilizers. In this study, pre-treated struvite as AM and IM were tested for leaching loss using soil columns and its effect as an eco-friendly and sustainable fertilizer source in Sudan grass production was evaluated. The column leaching tests elucidated that nutrient release from AM and IM were much slower than the commercial fertilizer (FSP) and therefore could supply the nutrients in the soil for a much longer period. Pre-treated struvite as a fertilizer thus can improve nutrient use efficiency and nutrient loss can also be reduced. Pot trials of Sudan grass showed no significant difference among the test materials except the control in terms of growth rate and fresh and dry matter yield $(p<0.05)$. When FSP, AM, and IM were applied in high doses (20x) without urea supplement, no significant difference was observed between AM and FSP treatments $(p>0.05)$. However, the dry matter percentage was significantly lower in FSP treatment $(22.2 \%)(p<0.05)$. Pre-treated struvite as AM could therefore be an effective alternative to commercial fertilizers in cultivating Sudan grass as it is released slowly and is readily available to the plants. Further studies are required to ascertain the potential eco-friendly application of IM.

Author Contributions: Conceptualization, A.R., S.S., S.W., and C.R.; methodology, S.W. and C.R.; formal analysis, S.S. and S.K.; investigation, S.S. and S.K.; resources, C.R.; data curation, A.R. and S.S.; software, A.R.; writing-original draft preparation, N.A. and A.R.; writing—-review and editing, A.R., S.W., and C.R.; supervision, S.W. and C.R.; project administration, C.R.; funding acquisition, C.R.

Funding: This research was funded by the Rural Development Administration of Korea, grant number PJ011623 and partially supported by Kangwon National University.

Conflicts of Interest: The authors declare no conflicts of interest. The funders had no role in the design of the study; in the collection, analyses, or interpretation of data; in the writing of the manuscript, or in the decision to publish the results.

\section{References}

1. Jasinski, S.M. Phosphate Rock, USGS Mineral Commodities Summary. Available online: http://minerals. usgs.gov/minerals/pubs/commodity/phosphate_rock/ (accessed on 25 July 2019).

2. Steen, I. Phosphorus availability in the 21st century: Management of a non-renewable resource. Phosphorus Potassium 1998, 217, 25-31.

3. Li, B.; Boiarkina, I.; Yu, W.; Huang, H.M.; Munir, T.; Wang, G.Q.; Young, B.R. Phosphorus recovery through struvite crystallization: Challenges for future design. Sci. Total Environ. 2019, 648, 1244-1256. [CrossRef] [PubMed]

4. Daneshgar, S.; Callegari, A.; Capodaglio, A.G.; Vaccari, D. The Potential Phosphorus Crisis: Resource Conservation and Possible Escape Technologies: A Review. Resources 2018, 7, 37. [CrossRef]

5. Anonymous Critical Raw Materials. Available online: http://ec.europa.eu/growth/sectors/raw-materials/ specific-interest/critical_en (accessed on 16 June 2019).

6. Managing Phosphorus for Agriculture and the Environment (Pennsylvania Nutrient Management Program). Available online: https://extension.psu.edu/programs/nutrient-management/educational/soilfertility/managing-phosphorus-for-agriculture-and-the-environment (accessed on 16 June 2019).

7. Crecchio, C.; Curci, M.; Mininni, R.; Ricciuti, P.; Ruggiero, P. Short-term effects of municipal solid waste compost amendments on soil carbon and nitrogen content, some enzyme activities and genetic diversity. Biol. Fertil. Soils 2001, 34, 311-318. [CrossRef]

8. Callegari, A.; Capodaglio, A.G. Properties and Beneficial Uses of (Bio)Chars, with Special Attention to Products from Sewage Sludge Pyrolysis. Resources 2018, 7, 20. [CrossRef]

9. Talboys, P.J.; Heppell, J.; Roose, T.; Healey, J.R.; Jones, D.L.; Withers, P.J.A. Struvite: A slow-release fertiliser for sustainable phosphorus management? Plant Soil 2016, 401, 109-123. [CrossRef] [PubMed] 
10. Withers, P.; Elser, J.; Hilton, J.; Ohtake, H.; Schipper, W.; van Dijk, K.C. Greening the global phosphorus cycle: How green chemistry can help achieve planetary P sustainability. Green Chem. 2015, 17, 2087-2099. [CrossRef]

11. Wang, F.; Fu, R.; Lv, H.; Zhu, G.; Lu, B.; Zhou, Z.; Wu, X.; Chen, H. Phosphate Recovery from Swine Wastewater by a Struvite Precipitation Electrolyzer. Sci. Rep. 2019, 9, 8893. [CrossRef]

12. Rech, I.; Withers, P.J.A.; Jones, D.L.; Pavinato, P.S. Solubility, Diffusion and Crop Uptake of Phosphorus in Three Different Struvites. Sustainability 2019, 11, 134. [CrossRef]

13. Armah-Agyeman, G.; Loiland, J.; Karow, R.; Bean, B. Sudangrass; Oregon State University: Corvallis, OR, USA, 2002.

14. Getachew, G.; Putnam, D.H.; Ben, C.M.D.; Peters, E.J.D. Potential of Sorghum as an Alternative to Corn Forage. Am. J. Plant Sci. 2016, 7, 1106. [CrossRef]

15. Al-Solaimani, S.G.; Alghabari, F.; Ihsan, M.Z.; Fahad, S. Water Deficit Irrigation and Nitrogen Response of Sudan Grass under Arid Land Drip Irrigation Conditions. Irrig. Drainage 2017, 66, 365-376. [CrossRef]

16. Torrecillas, M.; Cantamutto, M.A.; Bertoia, L.M. Head and Stover Contribution to Digestible Dry Matter Yield on Grain and Dual-purpose Sorghum Crop. Aust. J. Crop Sci. 2011, 5, 116.

17. Achat, D.L.; Sperandio, M.; Daumer, M.L.; Santellani, A.C.; Prud'Homme, L.; Akhtar, M.; Morel, C. Plant-availability of phosphorus recycled from pig manures and dairy effluents as assessed by isotopic labeling techniques. Geoderma 2014, 232-234, 24-33. [CrossRef]

18. Antonini, S.; Arias, M.A.; Eichert, T.; Clemens, J. Greenhouse evaluation and environmental impact assessment of different urine-derived struvite fertilizers as phosphorus sources for plants. Chemosphere 2012, 89, 1202-1210. [CrossRef] [PubMed]

19. Johnston, A.E.; Richards, I.R. Effectiveness of different precipitated phosphates as phosphorus sources for plants. Soil. Use Manag. 2003, 19, 45-49. [CrossRef]

20. Massey, M.S.; Davis, J.G.; Ippolito, J.A.; Sheffield, R.E. Effectiveness of recovered magnesium phosphates as fertilizers in neutral and slightly alkaline soils. Agron. J. 2009, 101, 323-329. [CrossRef]

21. Ahmed, N.; Shim, S.; Won, S.; Ra, C. Struvite recovered from various types of wastewaters: Characteristics, soil leaching behaviour, and plant growth. Land Degrad. Dev. 2018, 29, 2864-2879. [CrossRef]

22. Rahman, M.M.; Liu, Y.; Kwag, J.-H.; Ra, C. Recovery of struvite from animal wastewater and its nutrient leaching loss in soil. J. Hazard. Mater. 2011, 186, 2026-2030. [CrossRef]

23. AOAC. Official Methods of Analysis, 17th ed.; Association of Official Analytical Chemistry: Washington, DC, USA, 2003.

24. Yoon, T.; Lee, D.; Won, S.; Ra, C.; Kim, J. Optimal incorporation level of dietary alternative phosphate $\left(\mathrm{mghpo}_{4}\right)$ and requirement for phosphorus in juvenile far eastern catfish (Silurus asotus). Asian Australas. J. Anim. Sci. 2015, 28, 111-119. [CrossRef]

25. Hanhoun, M.; Montastruc, L.; Azzaro-Pantel, C.; Biscans, B.; Frèche, M.; Pibouleau, L. Temperature impact assessment on struvite solubility product: A thermodynamic modeling approach. Chem. Eng. J. 2011, 167, 50-58. [CrossRef]

26. Rural Development Administration (RDA). Criteria for the Application of Fertilizer to Crops; Rural Development Administration: Suwon, Korea, 2015.

27. APHA; AWWA; WEF; WPCF. Standard Methods for the Examination of Water and Wastewater, 21st ed.; American Public Health Association: Washington, DC, USA, 2005.

28. Daneshgar, S.; Buttafava, A.; Capsoni, D.; Callegari, A.; Capodaglio, A.G. Impact of pH and Ionic Molar Ratios on Phosphorous Forms Precipitation and Recovery from Different Wastewater Sludges. Resources 2018, 7, 71. [CrossRef]

29. Daneshgar, S.; Vanrolleghem, P.A.; Vaneeckhaute, C.; Buttafava, A.; Capodaglio, A.G. Optimization of $\mathrm{P}$ compounds recovery from aerobic sludge by chemical modeling and response surface methodology combination. Sci. Total Environ. 2019, 668, 668-677. [CrossRef]

30. Liu, Y.; Rahman, M.M.; Kwag, J.H.; Kim, J.H.; Ra, C. Eco-friendly Production of Maize Using Struvite Recovered from Swine Wastewater as a Sustainable Fertilizer Source. Asian Australas. J. Anim. Sci. 2011, 24, 1699-1705. [CrossRef]

31. Bao, X.D.; Ye, Z.L.; Ma, J.H.; Chen, S.H.; Lin, L.F.; Yan, Y.J. Effect of pH on Precipitate Composition During Phosphorus Recovery as Struvite from Swine Wastewater. Environ. Sci. 2011, 32, 2598-2603. 
32. Korean Statistical Information Service (KOSIS). Livestock Population Trend (Swine). Available online: http://kosis.kr/statisticsList/statisticsListIndex.do?menuId=M_01_01\&vwcd=MT_ZTITLE\&parmTabId= M_01_01\&statId=1976076\&themaId=F\#F1A.3 (accessed on 28 July 2019).

33. Rural Development Administration (RDA). Centralized Livestock Wastewater Treatment Plan 2019; Rural Development Administration: Jeonju, Korea, 2019.

34. Ministry of Environment (MoE). Establishment and Operation of Centralized Livestock Wastewater Treatment Plant; Ministry of Environment: Sejong, Korea, 2018.

35. Mujumder, A.S. Handbook of Industrial Drying, 4th ed.; CRC press: Boca Raton, FL, USA, 2014; p. 616.

36. Mayol, A.P.; Ubando, A.; Biona, J.B.; Ong, H.L.; Espiritu, R.; Lee, H.; Tumlos, R.; Arboleda, N.; Culaba, A.B. Investigation of the drying characteristics of microalgae using microwave irradiation. In Proceedings of the International Conference on Humanoid, Nanotechnology, Information Technology, Communication and Control, Environment and Management (HNICEM), Cebu, Philippines, 9-12 December 2015.

37. Kataki, S.; West, H.; Clarke, M.; Baruah, D.C. Phosphorus recovery as struvite: Recent concerns for use of seed, alternative Mg source, nitrogen conservation and fertilizer potential. Resour. Conserv. Recycl. 2016, 107, 142-156. [CrossRef]

38. Latifian, M.; Liu, J.; Mattiasson, B. Struvite-based fertilizer and its physical and chemical properties. Environ. Technol. 2012, 33, 2691-2697. [CrossRef]

39. Sharma, R.; Bell, R.W.; Wong, M.T.F. Dissolved reactive phosphorus played a limited role in phosphorus transport via runoff, throughflow and leaching on contrasting cropping soils from southwest Australia. Sci. Total Environ. 2017, 577, 33-44. [CrossRef]

40. Ryu, H.D.; Lee, S.I. Struvite recovery from swine wastewater and its assessment as a fertilizer. Environ. Eng. Res. 2016, 21, 29-35. [CrossRef]

41. Ryu, H.D.; Lim, C.S.; Kim, Y.K.; Kim, K.Y.; Lee, S.I. Recovery of struvite obtained from semiconductor wastewater and reuse as a slow-release fertilizer. Environ. Eng. Sci. 2012, 29, 540-548. [CrossRef]

42. Doyle, J.D.; Parsons, S.A. Struvite formation, control and recovery. Water Res. 2002, 36, 3925-3940. [CrossRef]

43. Li, X.Z.; Zhao, Q.L. Recovery of ammonium-nitrogen from landfill leachate as a multi-nutrient fertilizer. Ecol. Eng. 2003, 20, 171-181. [CrossRef]

44. Ryu, H.D.; Lim, C.S.; Kang, M.K.; Lee, S.I. Evaluation of struvite obtained from semiconductor wastewater as a fertilizer in cultivating Chinese cabbage. J. Hazard. Mater. 2012, 221-222, 248-255. [CrossRef]

45. Plaza, C.; Sanz, R.; Clemente, C.; Fernández, J.M.; González, R.; Polo, A.; Colmenarejo, M.F. Greenhouse Evaluation of Struvite and Sludges from Municipal Wastewater Treatment Works as Phosphorus Sources for Plants. J. Agric. Food Chem. 2007, 55, 8206-8212. [CrossRef]

46. Ackerman, J.N.; Zvomuya, F.; Cicek, N.; Flaten, D. Evaluation of manure-derived struvite as a phosphorus source for canola. Can. J. Plant Sci. 2013, 93, 419-424. [CrossRef]

47. Uysal, A.; Demir, S.; Sayilgan, E.; Eraslan, F.; Kucukyumuk, Z. Optimization of struvite fertilizer formation from baker's yeast wastewater: Growth and nutrition of maize and tomato plants. Environ. Sci. Pollut. Res. Int. 2014, 21, 3264-3274. [CrossRef]

48. González-Ponce, R.; López-de-Sá, E.G.; Plaza, C. Lettuce response to phosphorus fertilization with struvite recovered from municipal wastewater. Hortscience 2009, 44, 426-430. [CrossRef]

(C) 2019 by the authors. Licensee MDPI, Basel, Switzerland. This article is an open access article distributed under the terms and conditions of the Creative Commons Attribution (CC BY) license (http://creativecommons.org/licenses/by/4.0/). 